\title{
Phytochemical and antimicrobial evaluation of selected medicinal plants in Meru community of Kenya

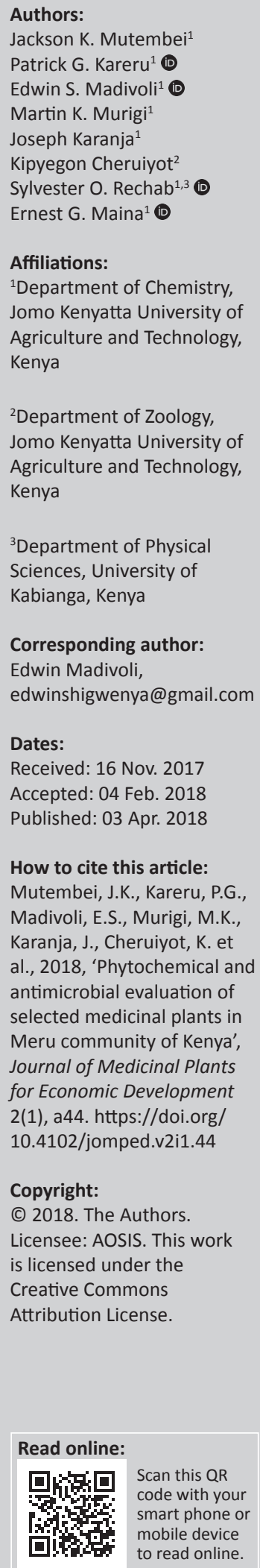

Background: Increased resistance against antimicrobial medication used to combat bacterial infection necessitates the need for alternative medication.

Objective: This study seeks to evaluate the antimicrobial potential and phytochemical profiles of 10 medicinal plants collected from Chuka, Tharaka-Nithi County of Kenya. Plant samples were collected, dried, pulverised into fine powders and extracted with distilled water.

Methodology: Qualitative phytochemical screening and disc-agar diffusion methods were used according to standard method to determine phytochemical profile and antimicrobial activity of the aqueous extracts against four bacterial strains and a fungus.

Results: Phytochemical investigation revealed the presence of terpenoids, tannins and reducing sugars in all the plants except one. Saponins were found to be present in Albizia anthelmintica, Entada leptostachya, Raponae rhododendroides and Warbugia ugandensis. Steroids were present in seven plants while alkaloids were present in five. Albizia anthelmintica, E. leptostachya and W. ugandensis extracts were active against Staphylococcus aureus, Bacillus subtilis, Pseudomonas aeruginosa, Escherichia coli and Candida albicans. Escherichia coli was the most susceptible bacteria against all the plant extracts tested, except Harrisonia abyssinica. Vernonia lasiopus and Uvariodendron anisatum were the least active extracts. Susceptibility against E. coli and C. albicans was significantly comparable to benzathine penicillin and streptomycin.

Conclusion: The type of ailments the plants are claimed to treat can be attributed to the presence of various classes of phytochemicals. In conclusion, the plants evaluated were found to be active against the microorganisms tested.

\section{Introduction}

Antibiotics are the main basis for therapy provision of bacterial and fungal infections (Khan et al. 2009). Since their discovery, it was believed that this would eventually lead to the eradication of infectious diseases. On the contrary, overuse and indiscriminate use of antibiotics have led to the emergence of multidrug-resistant strains of several groups of microorganisms (Harbottle et al. 2006; Khan et al. 2009; Wagate et al. 2009), and this has become a global concern (Parekh \& Chanda 2007). The emergence of multidrug-resistant pathogens threatens the clinical efficacy of many existing antibiotics (Parekh \& Chanda 2007). Escherichia coli, Klebsiella pneumoniae, Haemophilus spp. and many other B-lactamase producers have emerged and have become a major therapeutic problem in the world today. Multidrug-resistant strains of E. coli and K. pneumoniae are widely distributed in hospitals (Khan \& Musharraf 2004). These strains are increasingly being isolated from community-acquired infections (Akram, Shahid \& Khan 2007). Candida albicans, also a nosocomial pathogen, has been reported to account for $50 \%-70 \%$ cases of invasive candidiasis (Paula et al. 2006). In addition, the life expectancy of antimicrobial agents remains a challenge to researchers because the emergence of resistance to newly introduced antimicrobial agents indicates that new families of antimicrobial agents have a short life expectancy (Coates et al. 2002). Hence, there is an urgent need to shift attention to natural products to develop better drugs that can combat multiple drug-resistant bacterial strains (Parekh \& Chanda 2007).

Medicinal plants have been recognised as potential sources of such compounds (Table 1) (Wagate et al. 2010).

Research findings have shown that ethnobotanically-derived compounds have greater activity than compounds derived from random screening and thus they pose a greater potential for novel products (Flaster 1996; Njoroge \& Bussmann 2006). Because of their unmatched availability and chemical diversity, both pure compounds and standardised plant extracts provide unlimited 
TABLE 1: Medicinal plant parts used and their therapeutic indications.

\begin{tabular}{|c|c|c|c|}
\hline Plant species & Trivial name & Parts used & Therapeutic indication \\
\hline $\begin{array}{l}\text { Warbugia } \\
\text { ugandensis }\end{array}$ & Muthiga & Barks & $\begin{array}{l}\text { Gonorrhoea, tooth ache, } \\
\text { malaria and anaplasmosis }\end{array}$ \\
\hline $\begin{array}{l}\text { Uvariodendron } \\
\text { anisatum }\end{array}$ & Ntonga & Whole & $\begin{array}{l}\text { Stomach ache and } \\
\text { anaplasmosis }\end{array}$ \\
\hline Carrisa edulis & Mukawa & Roots & $\begin{array}{l}\text { Decoction of the roots is used } \\
\text { to treat malaria }\end{array}$ \\
\hline $\begin{array}{l}\text { Harrisonia } \\
\text { abyssinica }\end{array}$ & Mutagata & Roots & $\begin{array}{l}\text { Decoction of the roots is used } \\
\text { to treat malaria }\end{array}$ \\
\hline $\begin{array}{l}\text { Albizia } \\
\text { anthelmintica }\end{array}$ & Mubarwa & Barks & $\begin{array}{l}\text { Infusion of the barks is used } \\
\text { as anthelmintic }\end{array}$ \\
\hline $\begin{array}{l}\text { Zanthoxylum } \\
\text { usambarensis }\end{array}$ & Mugucwa & Barks & $\begin{array}{l}\text { Decoction of the backs is used } \\
\text { to treat malaria }\end{array}$ \\
\hline $\begin{array}{l}\text { Senna } \\
\text { didymobotrya }\end{array}$ & Mwinu & Leaves & $\begin{array}{l}\text { Decoction of the leaves is } \\
\text { used to treat malaria }\end{array}$ \\
\hline Vernonia lasiopus & Mucatha & Leaves & $\begin{array}{l}\text { Infusion of the leaves is used } \\
\text { as anthelmintic }\end{array}$ \\
\hline $\begin{array}{l}\text { Entada } \\
\text { leptostachya }\end{array}$ & Mwaritha & Barks/roots & $\begin{array}{l}\text { Infusion of the barks and } \\
\text { roots is used as anthelmintic }\end{array}$ \\
\hline $\begin{array}{l}\text { Raponae } \\
\text { rhododendroides }\end{array}$ & Mugeta & Barks & $\begin{array}{l}\text { Infusion of the barks is used } \\
\text { as anthelmintic }\end{array}$ \\
\hline
\end{tabular}

Source: Wagate et al. 2010

TABLE 2: Phytochemical profiles of the aqueous plant extracts.

\begin{tabular}{|c|c|c|c|c|c|c|c|c|}
\hline Plant Species & SA & $\mathrm{AL}$ & $\mathrm{TE}$ & ST & CG & AN & TA & RS \\
\hline L. eriocalyx & +++ & - & + & + & - & + & + & ++ \\
\hline $\begin{array}{l}\text { Warbugia } \\
\text { ugandensis }\end{array}$ & + & - & + & + & - & - & + & + \\
\hline $\begin{array}{l}\text { Albizia } \\
\text { anthelmintica }\end{array}$ & +++ & + & + & + & + & - & + & - \\
\hline $\begin{array}{l}\text { Entada } \\
\text { leptostachya }\end{array}$ & +++ & + & + & + & + & - & + & + \\
\hline Carrisa edulis & - & - & + & + & - & - & + & + \\
\hline $\begin{array}{l}\text { Senna } \\
\text { didymobotrya }\end{array}$ & - & - & - & - & - & + & + & + \\
\hline $\begin{array}{l}\text { Uvariodendron } \\
\text { anisatum }\end{array}$ & - & - & + & + & - & + & + & + \\
\hline A. indica & - & - & - & - & - & - & + & + \\
\hline A. remota & + & - & + & + & + & - & + & - \\
\hline $\begin{array}{l}\text { Harrisonia } \\
\text { abyssinica }\end{array}$ & - & - & + & + & + & - & - & ++ \\
\hline $\begin{array}{l}\text { Zanthoxylum } \\
\text { usambarensis }\end{array}$ & - & + & + & + & - & - & + & ++ \\
\hline Vernonia lasiopus & ++ & + & + & - & - & + & + & + \\
\hline $\begin{array}{l}\text { Raponae } \\
\text { rhododendroides }\end{array}$ & +++ & + & + & - & - & + & + & + \\
\hline
\end{tabular}

not detected; +, detected; ++, moderately detected; +++, detected in large amount; SA saponins; Al, alkaloids; TE, terpenoids; ST, steroids; CG, cardiac glycosides; AN anthraquinones; TA, tannins; RS, reducing sugars.

opportunities for development of new drugs (Parekh \& Chanda 2007). Natural products have been used in traditional medicine all over the world for thousands of years and they predate the introduction of antibiotics and other modern drugs (Balunas \& Kinghorn 2005; Kareru et al. 2007; Khan et al. 2009; Parekh \& Chanda 2007). Plants are rich in a wide variety of secondary metabolites called phytochemicals, such as tannins, alkaloids and flavonoids, that have been found to have antimicrobial properties (Lewis \& Ausubel 2006). Medicinal plants have been reported to cure urinary tract infections, gastrointestinal disorders, respiratory diseases and cutaneous infections (de Boer et al. 2005). For example, the essential oil and eugenol purified from Ocimum gratissimum has been reported to treat pneumonia, diarrhoea and conjunctivitis (Nakamura et al. 1999). These evidences contribute to support and quantify the importance of screening natural products. The aim of this study was to investigate the antibacterial and antifungal activity of aqueous and methanolic extracts of some selected plants used in the rural communities of Chuka in Meru South District of Kenya. The extracts were tested against four bacterial strains and C. albicans, a fungus.

\section{Materials and methods Collection and preparation of plant materials}

Ten medicinal plant samples (Table 2) were collected from Marembo village in Chuka, Meru South District of TharakaNithi County in Kenya based on ethnopharmacological use through interviews with traditional medicine practitioners in the area. Information gathered included vernacular names, plant parts used and the method of preparation and administration of herbal remedies. Botanical identity of the plants was done by a botanist from the Department of Botany, Jomo Kenyatta University of Agriculture and Technology, Kenya. The samples were then chopped into small pieces after thorough washing in running water and air-dried on the laboratory bench at room temperature ranging from $23^{\circ} \mathrm{C}$ to $26^{\circ} \mathrm{C}$ for four weeks. The dried plant samples were ground into a fine powder using an in-house mechanical mill.

\section{Extraction of plant material}

Extraction was carried out using distilled water and methanol as extraction solvents to obtain respective aqueous and methanolic extracts. Aqueous extraction was carried out by soaking $5 \mathrm{~g}$ of the plant powder of every plant sample in $100 \mathrm{~mL}$ hot distilled water for $2 \mathrm{~h}$. The aqueous extracts obtained were filtered in a Whatman Filter Paper No. 1 and analysed immediately. Methanol extraction was carried out by weighing $5 \mathrm{~g}$ of the fine powdered material and macerating in $200 \mathrm{~mL}$ methanol for four days at room temperature. The methanol extracts were filtered using Whatman Filter Paper No. 1 and concentrated using a Rota evaporator at $40^{\circ} \mathrm{C}$ left to dry in a fume chamber, after which they were stored at $4^{\circ} \mathrm{C}$ for analysis.

\section{Phytochemical analysis}

Qualitative phytochemical screening for the detection of plant metabolites was carried out on both the aqueous and methanol extracts using standard procedures as described in the literature (Harbone 1973). An aliquot of every plant extract was analysed for the presence of saponins, alkaloids, terpenoids, steroids, cardiac glycosides, anthraquinones, tannins and reducing sugars.

\section{Antimicrobial analysis}

Filter paper disc-agar diffusion procedure, known as the Kirby-Bauer method (Bauer et al. 1966), was used to determine the drug susceptibility of Pseudomonas aeruginosa, E. coli, Bacillus subtilis, Staphylococcus aureus and C. albicans. These microorganisms were obtained from the Department of Botany.

\section{Media preparation}

Mueller-Hinton nutrient agar was prepared by boiling $56 \mathrm{~g}$ to dissolve in $2 \mathrm{~L}$ of distilled water. The agar was autoclaved 
at $121^{\circ} \mathrm{C}$ for $15 \mathrm{~min}$ and left to cool, after which it was dispensed in sterile petri dishes and allowed to solidify. The solid agar was incubated at $37^{\circ} \mathrm{C}$ for $24 \mathrm{~h}$. Paper disks were punched from filter papers and autoclaved at $121^{\circ} \mathrm{C}$ for $15 \mathrm{~min}$.

\section{Preparation of cultures}

Bacteria strains of P. aeruginosa, E. coli, B. subtilis, S. aureus and C. albicans were subcultured in nutrient broth and incubated at $37^{\circ} \mathrm{C}$ for $24 \mathrm{~h}$.

\section{Procedure}

Using a pipette, $0.1 \mathrm{~mL}$ of a 24 -h culture was drawn and placed in the nutrient agar and spread using a spreader. Paper discs were then soaked in each plant extract using a sterile forceps and placed in duplicate on the bacteria in the nutrient agar. They were then incubated for $24 \mathrm{~h}$, after which zones of inhibition were measured in millimetres.

\section{Results and discussions Qualitative phytochemical screening}

Qualitative phytochemical analysis is an important step in drug discovery as it gives information about the presence of primary or secondary metabolite(s) in plant extracts that is (or are) of therapeutic significance (Ganatra, Durge \& Patil 2012). The presence of bioactive phytoconstituents may then be further explored for the isolation and purification of a possible drug lead compound (Ganatra et al. 2012). The results of phytochemical screening (Table 2) exhibited positive test for terpenoids, tannins and reducing sugars in all the plants except Senna didymobotrya, Harrisonia abyssinica and Albizia anthelmintica, respectively. Saponins were found to be present in Vernonia lasiopus, A. anthelmintica, Entada leptostachya, Raponae rhododendroides and Warbugia ugandensis. Steroids were found to be present in A. anthelmintica, E. leptostachya, W. ugandensis, Uvariodendron anisatum, $H$. abyssinica and Zanthoxylum usambarensis, while V. lasiopus, A. anthelmintica, E. leptostachya, R. rhododendroides and
Z. usambarensis contained alkaloids. Anthraquinones were found to be present only in $V$. lasiopus, $R$. rhododendroides and U. anisatum.

\section{Antimicrobial activity}

Antimicrobial evaluation findings (Table 3) show that $A$. anthelmintica, E. leptostachya and W. ugandensis extracts were active against all the clinical isolated bacterial strains tested (S. aureus, B. subtilis, P. aeruginosa and E. coli) and the fungus, C. albicans. Escherichia coli was found to be the most susceptible bacteria against all the plant extracts under investigation except $H$. abyssinica. Pseudomonas aeruginosa was the second most susceptible bacteria. However, V. lasiopus and Uvariodendron anisatum were the least active extracts. The activity of all the plant extracts tested revealed antimicrobial activity against E. coli and C. albicans that was significantly comparable to that of benzathine penicillin and streptomycin, the conventional antibiotics used as positive control in our investigations. Benzathine penicillin is a small-spectrum penicillin with a bactericidal action against mainly grampositive bacteria like Staphylococcus aureus and Streptococcus spp., while dihydrostreptomycin is an aminoglycoside with a bactericidal action against mainly gram-negative bacteria like E. coli.

The antimicrobial properties of the plant extracts, except $H$. abyssinica, can be attributed to the presence of tannins which have been reported to exert antimicrobial as well as anthelmintic properties (Athanasiadou et al. 2001). Albizia anthelmintica, E. leptostachya and W. ugandensis extracts have been reported to have antimicrobial properties because of the presence of saponins isolated from crude extracts of these plants. Warburganal and muzigadial isolated from W. ugandensis exhibited very potent antifungal properties (Avato et al. 2006; Mwitari et al. 2013). Antibacterial properties of Trichosanthes cucumerina have also been reported to be a result of carotenoids, flavonoids, lycopene, phenolics and B-carotene present in its seed (Reddy et al. 2010). The dried seeds of the plant are used as anthelmintic and antidiarrhoeal agents, and the seeds are also used in India for their antibacterial, antispasmodic and

TABLE 3: Antimicrobial susceptibility tests of extracts from surveyed plants.

\begin{tabular}{|c|c|c|c|c|c|}
\hline \multirow[t]{3}{*}{ Plant } & \multicolumn{5}{|c|}{ Inhibition zone diameter (mm) } \\
\hline & \multicolumn{2}{|c|}{ Gram-positive bacteria } & \multicolumn{2}{|c|}{ Gram-negative bacteria } & \multirow{2}{*}{$\begin{array}{c}\text { Fungi } \\
\text { C. albicans }\end{array}$} \\
\hline & S. aureus & B. subtilis & P. aeruginosa & E. coli & \\
\hline Vernonia lasiopus & 0 & 0 & $9.0 \pm 0.6$ & $10.5 \pm 0.3$ & 0 \\
\hline Albizia anthelmintica & $11.5 \pm 0.2$ & $8.1 \pm 0.4$ & $10.5 \pm 0.8$ & $9.0 \pm 0.1$ & $10.0 \pm 0.2$ \\
\hline Entada leptostachya & $11.3 \pm 0.1$ & $12.5 \pm 0.4$ & $8.5 \pm 1.0$ & $9.5 \pm 0.6$ & $10.0 \pm 0.3$ \\
\hline Raponae rhododendroides & $11.1 \pm 0.2$ & $7.5 \pm 1.0$ & 0 & $10.0 \pm 0.4$ & 0 \\
\hline Warbugia ugandensis & $9.1 \pm 0.1$ & $9.4 \pm 0.5$ & $8.5 \pm 0.4$ & $9.4 \pm 0.4$ & $9.5 \pm 0.5$ \\
\hline Carrisa edulis & $9.0 \pm 0.0$ & 0 & $8.5 \pm 0.4$ & $7.0 \pm 1.0$ & 0 \\
\hline Senna didymobotrya & 0 & $7.2 \pm 0.3$ & $9.6 \pm 0.8$ & $7.0 \pm 0.2$ & $9.5 \pm 0.3$ \\
\hline Uvariodendron anisatum & $9.2 \pm 0.3$ & 0 & 0 & $9.5 \pm 0.3$ & 0 \\
\hline Harrisonia abyssinica & $10.5 \pm 0.2$ & $9.5 \pm 0.4$ & $8.5 \pm 0.6$ & 0 & $7.1 \pm 0.1$ \\
\hline Zanthoxylum usambarensis & 0 & $8.0 \pm 0.5$ & $8.5 \pm 0.4$ & $10.5 \pm 0.1$ & $8.0 \pm 0.1$ \\
\hline Benzathine penicillin & $38.3 \pm 0.4$ & $21.2 \pm 0.3$ & $52.6 \pm 0.8$ & $11.5 \pm 0.2$ & $19.2 \pm 0.1$ \\
\hline Streptomycin & $44.5 \pm 0.2$ & $40.1 \pm 0.5$ & $44.1 \pm 0.2$ & $30.0 \pm 0.2$ & $16.1 \pm 0.1$ \\
\hline
\end{tabular}

Note: Diameter of disc (6 mm), (0) no inhibition, Staphylococcus aureus, Bacillus subtilis, Pseudomonas aeruginosa, Escherichia coli, Candida albicans. 
insecticidal properties (Reddy et al. 2010). Similar antimicrobial properties of $H$. abyssinica and E. leptostachya have been reported. Wagate et al. (2010) reported that the extract of E. leptostachya showed appreciable inhibitory activity against Bacillus cereus and P. aeruginosa. On the contrary, H. abyssinica was reported by the same authors to have inhibitory activity against Micrococcus lutea, B. cereus, P. aeruginosa and E. coli. Consequently, the presence of high concentrations of saponins in this work is an indication that further work needs to be carried out to isolate and characterise the saponins and other phytochemicals present in these African medicinal plants under study. Thus, the presence of various phytochemicals found in this work can be associated with these antimicrobial properties and support their use by the communities in Tharaka-Nithi County of Kenya.

\section{Conclusion}

There exists a correlation between antimicrobial activity observed and phytoconstituents in the plants under study. Albizia anthelmintica, E. leptostachya and W. ugandensis extracts that were found to be active against S. aureus, B. subtilis, $P$. aeruginosa, E. coli and the fungus $C$. albicans contained saponins and tannins. The presence of reducing sugars in the three plants implies that the particular classes of saponins and tannins present could be bonded through a glycosidic bond to a sugar molecule. The various types of ailments the plants are claimed to treat may be scientifically justified (or offered a scientific basis for their folklore therapeutic use) by associating some of the detected phytoconstituents as being responsible for effecting the said cure or relief from symptoms mentioned in Table 2. Consequently, tannins and flavonoids have been documented to exert antimicrobial effect because of their astringent and polyphenolic nature (Wagate et al, 2010). The antimicrobial potentiality exhibited by these plants implies and justifies the need for further intensive research to isolate and characterise active phytochemicals that can combat microbial resistance exhibited by existing antibiotics.

\section{Acknowledgements}

The authors acknowledge the support of the Department of Botany at Jomo Kenyatta University of Agriculture and Technology for provision of the microbial stains used in this study.

\section{Competing interests}

The authors declare that they have no financial or personal relationships which may have inappropriately influenced them in writing this article.

\section{Authors' contributions}

E.S.M. was responsible for drafting the manuscript. J.K.M., E.G.M., J.K., M.K.M., K.C. and S.O.R. were responsible for sample collection and microbial analysis of the different plants. P.G.K. was the principal researcher and supervisor of the study.

\section{References}

Akram, M., Shahid, M. \& Khan, A.U., 2007, 'Etiology and antibiotic resistance patterns of community-acquired urinary tract infections in JNMC Hospital Aligarh, India', Annals of Clinical Microbiology and Antimicrobials 6(1), 4. https://doi. org/10.1186/1476-0711-6-4

Athanasiadou, S., Kyriazakis, I., Jackson, F. \& Coop, R.L., 2001, 'Direct anthelmintic effects of condensed tannins towards different gastrointestinal nematodes of sheep: In vitro and in vivo studies', Veterinary Parasitology 99(3), 205-219. https://doi.org/10.1016/S0304-4017(01)00467-8

Avato, P., Bucci, R., Tava, A., Vitali, C., Rosato, A., Bialy, Z. et al., 2006, 'Antimicrobial activity of saponins from Medicago sp.: Structure-activity relationship', Phytotherapy Research 20(6), 454-457. https://doi.org/10.1002/ptr.1876

Balunas, M.J. \& Kinghorn, A.D., 2005, 'Drug discovery from medicinal plants', Life Sciences 78(5), 431-441. https://doi.org/10.1016/j.lfs.2005.09.012

Bauer, A.W., Kirby, W.M., Sherris, J.C. \& Turck, M., 1966, 'Antibiotic susceptibility testing by a standardized single disk method', American Journal of Clinical Pathology 45(4), 493. https://doi.org/10.1093/ajcp/45.4_ts.493

Coates, A., Hu, Y., Bax, R. \& Page, C., 2002, 'The future challenges facing the development of new antimicrobial drugs', Nature Reviews Drug Discovery 1(11), 895-910. https://doi.org/10.1038/nrd940

de Boer, H.J., Kool, A., Broberg, A., Mziray, W.R., Hedberg, I. \& Levenfors, J.J., 2005, 'Anti-fungal and anti-bacterial activity of some herbal remedies from Tanzania', Journal of Ethnopharmacology 96(3), 461-469. https://doi.org/10.1016/j. jep.2004.09.035

Flaster, T., 1996, 'Ethnobotanical approaches to the discovery of bioactive compounds. Progress in new crops', in Proceedings of the Third National Symposium, ASHS Press, Alexandria, pp. 561-565.

Ganatra, S.H., Durge, S.P. \& Patil, S.U., 2012, 'Preliminary phytochemicals investigation and TLC analysis of Ficus racemosa leaves', Journal of Chemical and Pharmaceutical Research 4(5), 2380-2384.

Harbone, J.B., 1973, Phytochemical methods, Chapman and Hall Ltd, London, pp. 49-188.

Harbottle, H., Thakur, S., Zhao, S. \& White, D.G., 2006, 'Genetics of antimicrobial resistance', Animal Biotechnology 17(2), 111-124. https://doi.org/10.1080 /10495390600957092

Kareru, P.G., Kenji G.M., Gachanja A.N., Keriko J.M. \& Mungai, G., 2007, 'Traditional medicines among the Embu and Mbeere peoples of Kenya', African Journal of Traditional Medicine 4(1), 75-86. https://doi.org/10.4314/ajtcam.v4i1.31193

Khan, A.U. \& Musharraf, A., 2004, 'Plasmid-mediated multiple antibiotic resistance in Proteus mirabilis isolated from patients with urinary tract infection', Medical Science Monitor: International Medical Journal of Experimental and Clinical Research 10(11), CR598-CR602.

Khan, R., Islam, B., Akram, M., Shakil, S., Ahmad, A.A., Ali, S.M. et al., 2009 'Antimicrobial activity of five herbal extracts against multi drug resistant (MDR) strains of bacteria and fungus of clinical origin', Molecules 14(2), 586-597. https:// strains of bacteria and fungus of clinicalo
doi.org/10.3390/molecules14020586

Lewis, K. \& Ausubel, F.M., 2006, 'Prospects for plant-derived antibacterials', Nature Biotechnology 24(12), 1504-1507. https://doi.org/10.1038/nbt1206-1504

Mwitari, P.G., Ayeka, P.A., Ondicho, J., Matu, E.N. \& Bii, C.C., 2013, 'Antimicrobia activity and probable mechanisms of action of medicinal plants of Kenya: Withania somnifera, Warbugia ugandensis, Prunus africana and Plectrunthus barbatus', PLoS One 8(6), e65619. https://doi.org/10.1371/journal.pone.0065619

Nakamura, C.V., Ueda-Nakamura, T., Bando, E., Melo, A.F.N., Cortez, D.A.G. \& Dias Filho, B.P., 1999, 'Antibacterial activity of Ocimum gratissimum L. essential oil', Memórias do Instituto Oswaldo Cruz 94(5), 675-678. https://doi.org/10.1590/ S0074-02761999000500022

Njoroge, G.N. \& Bussmann, R.W., 2006, 'Herbal usage and informant consensus in ethnoveterinary management of cattle diseases among the Kikuyus (Central Kenya)', Journal of Ethnopharmacology 108(3), 332-339. https://doi. org/10.1016/j.jep.2006.05.031

Parekh, J. \& Chanda, S., 2007, 'In vitro antimicrobial activity and phytochemical analysis of some Indian medicinal plants', Turkish Journal of Biology 31(1), 53-58.

Paula, C.R., Krebs, V.L., Auler, M.E., Ruiz, L.S., Matsumoto, F.E., Silva, E.H. et al., 2006, 'Nosocomial infection in newborns by Pichia anomala in a Brazilian intensive care unit', Medical Mycology 44(5), 479-484. https://doi.org/10.1080/13693 780600561809

Reddy, L.J., Jose, B.E.E.N.A., Anjana, J.C. \& Ruveena, T.N., 2010, 'Evaluation of antibacterial activity of Trichosanthes cucumerina L. and Cassia didymobotrya Fres. Leaves', International Journal Pharmacy and Pharmceutical Science 2(4), 153-155.

Wagate, C.G., Mbaria, J.M., Gakuya, D.W., Nanyingi, M.O., Kareru, P.G., Njuguna, A et al., 2010, 'Screening of some Kenyan medicinal plants for antibacterial activity', Phytotherapy Research 24(1), 150-153. https://doi.org/10.1002/ptr.2866 